Virginia Commonwealth University VCU Scholars Compass

2015

\title{
Moving Users, Moving Results: Exploring Customer Engagement for Deeper Relationships
}

Bettina Peacemaker

Virginia Commonwealth University, bjpeacemaker@vcu.edu

Jill Stover Heinze

University of Virginia, jh9xp@virginia.edu

Follow this and additional works at: http://scholarscompass.vcu.edu/libraries_pubs

Part of the Library and Information Science Commons

\section{Downloaded from}

http://scholarscompass.vcu.edu/libraries_pubs/34

This Article is brought to you for free and open access by the VCU Libraries at VCU Scholars Compass. It has been accepted for inclusion in VCU Libraries Faculty and Staff Publications by an authorized administrator of VCU Scholars Compass. For more information, please contact libcompass@vcu.edu. 
Moving Users, Moving Results: Exploring Customer Engagement 1

\title{
Moving Users, Moving Results: Exploring Customer Engagement for Deeper Relationships
}

Bettina Peacemaker, Virginia Commonwealth University Libraries, bjpeacemaker@vcu.edu Jill Stover Heinze, University of Virginia Library, h9xp@virginia.edu

\begin{abstract}
Successful businesses know that customers make purchase decisions based on a complex bundle of rational and emotional factors that vary in degree and importance depending upon the context. In crowded markets where potential customers have many comparable options, it is often the emotional relationships that they have with businesses that influence where they spend their dollars. Recognizing this reality, businesses have been shifting from transacting with customers to "engaging" with them. This paper outlines the need for librarians to understand engagement more fully, and it points to guidance from the business literature on how to define and create engagement.
\end{abstract}

Keywords: engagement, academic librarians, customer engagement, marketing, liaison librarians

\section{Introduction}

At first glance private sector businesses and academic libraries appear to be driven by completely disparate stakeholders, objectives, and competitive pressures. Most librarians do not fill their days creating strategies to meet revenue targets, outmaneuver competitors, and monitor cash flow. Librarians are more likely to be measuring linear feet and counting numbers of reference questions rather than calculating profit margins and cart abandonment rates. These 
differences, however, should not create the false impression that the business and library worlds operate independently. They are both part of a larger marketplace in which organizations seek to create value for customers.

Colleges and universities currently face strained budgets while also confronting new challenges and competitive forces. Economic pressures, changing demographic patterns, and the ubiquity of technology mean changing definitions of the traditional student and new expectations for the traditional educational experience. Competition from the for-profit sector and increasing demand for customized and convenient learning require new business models focused on enhancing the value of the college degree (Van Der Werf and Sabatier 2009).

Academic libraries operate within this broader higher education landscape and must also adapt to carve out new roles and find innovative ways to create value for their users. Changing research behaviors require attention to trends in service provision such as research data services and digital humanities, as well as support for new learning formats such as MOOCs (massive open online courses) and scholarly communication patterns (Association of College and Research Libraries 2015). Libraries are also creating new physical spaces that offer flexibility for creative and collaborative work and experimentation with technology (ACRL, 16-17). Traditional desk services are being evaluated as reference transactions decline, and liaison librarians are moving off the desk to become embedded with their users. All of these examples reflect a new engagement model of library services where the user is the focus. Librarians are embracing the concept of 'engagement' as both a useful rhetorical device and a substantive strategic necessity to anchor themselves to user needs and thereby remain relevant amidst the upheaval. 
Moving Users, Moving Results: Exploring Customer Engagement 3

Likewise, many in the business community have been steadily migrating resources toward engaging, rather than just transacting, with customers. In fact, this shift in tactics has been underway for over a decade, accelerated in recent years by the aftermath of the Great Recession of 2007-2009. Since both libraries and businesses are grappling with the same market forces via customer engagement, it is worthwhile to explore what library professionals can learn from parallel activities in the private sector.

\section{Library Engagement and the Liaison}

Engagement is a common theme in a variety of library contexts, but liaisons are increasingly viewed as catalysts for engagement. A report in the Association of Research Libraries' New Roles for New Times series examines evolving liaison roles, calling for an engagement model that looks outward to "enhance scholar productivity, to empower learners, and to participate in the entire lifecycle of the research, teaching, and learning process" (Jaguszewski and Williams 2013, 4). This level of involvement requires close, highly collaborative relationships with faculty, researchers, and students.

Discussion of the engagement concept in the library literature focuses on those relationships. After reviewing academic library strategic documents and interviewing representatives from eight libraries, Gibson and Dixon developed a definition for academic library engagement:

Sustained, strategic positioning of the academic library, through new or redirected resources, to create collaborative relationships with identified parties in order to advance institutional, community, and societal goals; through a progression of activities ranging from one-time initiatives, to longer-term projects, to enduring partnerships; to solve institutional- and community-level problems, or to support broad efforts to address long- 
range societal issues, through a range of engaged activities to create new knowledge, new products and services through these strategic choices; and to effect qualitatively different roles for academic libraries themselves through influential, reciprocal, and valueenhancing relationships of mutual benefit to libraries and the varied constituents and publics with whom they collaborate $(2011,347)$.

Although the definition focuses on broader institutional concerns rather than individual liaison efforts, it still speaks to the strategic importance of engagement and its ability to create value through relationships with partners outside the library. Bidney also highlights the importance of a mutually beneficial relationship while considering the distinction between outreach and engagement, "where the library-user outreach relationship is a one-way relationship, the libraryuser engagement relationship is mutually beneficial: the library or librarian gains as much as the user who is being engaged" $(2014,110)$.

Libraries have begun to create frameworks to formalize and assess new liaison roles, and engagement is often highlighted as a key component. The language used in these documents is consistent with the idea of engagement as a mutually beneficial relationship. A Framework for the Engaged Librarian from The Ohio State University Libraries describes engagement as "a deepened level of sustained, high-quality, mutually beneficial interaction in the liaison roles with academic programs" (The Ohio State University Libraries).

Competencies also focus on "develop[ing] strong working relationships" (Daniel et al. 2011, 2) and "developing partnerships...between the library and the assigned area" (The Ohio State University Libraries). Best practices offer some examples of relationship building techniques such as meeting and communicating regularly with faculty and participating in departmental events, as well as inviting interaction from departments in the form of user studies 
and other similar activities (Daniel et al. 2011; The Ohio State University Libraries). While these examples represent helpful ways to understand how engagement is understood by librarians, the concept needs more consideration to identify how to transform these interactions into engagement that is truly beneficial to both parties.

In research and practice, engagement is recognized as a critical element of mutual success for librarians and their users; yet, little empirical research exists in library literature to explain how to create and sustain engagement. The business literature, in contrast, provides a more robust body of work that can further librarians' understanding and application of engagement strategies.

\section{The Business of Engagement}

There was a time when successful customer relationships, at least from a company viewpoint, could be neatly summed up in terms of dollars and cents and units sold. This traditional approach is based on the premise that the locus of control resides with the company the company makes all product, advertising, and sales decisions. Consumers simply choose whether or not to make a purchase. Today, research shows that customers demand much more access and input into the companies they patronize.

A study of customer involvement done by Varki and Wong found that high-involvement customers - defined loosely as those who perceive that their purchase decisions have high "personal relevance" - demanded more access to companies than their low-involvement counterparts (2003). As the authors stated, "high-involvement customers had higher expectations that service providers treat them fairly and involve them in solutions to their problems" (89). Including customers as problem-solvers means that firms must cede some control to them for the potential benefit of capitalizing on their input. In their study of customer engagement behavior 
(CEB), Jaakkola and Alexander summarized this more modern approach to achieving business ends: "Contemporary thinking in many domains suggests that the roles of customer and seller are becoming increasingly blurred: Users participate in content creation and product development...support each other in product use..., and promote products, services and/or brands to other customers" $(2014,247)$.

As marketplace competition and pricing pressures intensify, companies are more and more drawn to the lure of nurturing an engaged customer base and including them in decisionmaking. The report, Beyond Loyalty by the Economist Intelligence Unit summed up the new environment and engagement imperative: "Most companies today face a two-fold dilemma. In many product and service categories, competition based on both price and quality is increasing...In this environment, the enterprise interested in winning, retaining and deepening customer relationships can no longer do so simply by creating a better product or even by holding down costs" (2007, Part 1:2). Instead, companies are discovering, "that the winning differentiator is no longer the product or the price, but the level of engagement--the degree to which a company succeeds in creating an intimate long-term relationship with the customer or external stakeholder" (2). According to this view, engagement is a means of achieving a sustainable competitive advantage in a crowded marketplace. After all, it is much more difficult for a customer to find a comparable, competitive service to one that she herself had a hand in making. A global survey of business executives reveals widespread acceptance of this conclusion, with 80 percent of respondents agreeing that "improved customer loyalty" is a benefit of achieving customer engagement (3).

While engagement strategies are markedly different from traditional ones, the need to create value for customers and realize profit goals for businesses remains paramount. The 
prospect of fostering close customer connections over time may seem like a costly, abstract, and questionably worthwhile objective. However, business research supports the conclusion that customer engagement is a profitable enterprise. An interview of twenty-seven business executives (including supervisors, managers, and vice presidents) supported the assertion that "engaging the customer can lead to successful marketing outcomes, such as word of mouth, receiving value, loyalty, share of wallet, and cross-selling” (Vivek, Beatty, and Morgan 2012, 131).

Gallup has been tracking American consumer behavior since 2008 in its State of the American Consumer: Insights for Business Leaders (2014). The report provides evidence that the relatively ethereal concept of engagement translates to quantifiable bottom-line benefits. Specifically, Gallup found that customers who are "fully engaged represent an average $23 \%$ premium in terms of share of wallet, profitability, revenue, and relationship growth over the average customer" (9). According to Gallup's metric, a "fully engaged" customer exhibits behaviors that most librarians would eagerly welcome, including going out of their way to patronize a service, refusing substitutes, and being emotionally attached (19). Although librarians do not track profitability, the fact that engagement has been shown to demonstrably produce desired, measurable results bolsters the case for pursuing an engagement strategy.

More anecdotally, some business practitioners, particularly those in marketing roles, have elevated the importance of engagement over more traditional goals. Frawley, the CEO of marketing and analytics firm Epsilon, advocates for a new approach to measuring business success. Rather than relying on the nearly-universal benchmark of Return on Investment (ROI), he proposes a benchmark that he calls " $\mathrm{ROE}^{2}$ (return on experience x engagement)" (2015). Frawley contends, “There's a point at which a customer's positive or negative experience is so 
strong that it can transcend the rational aspects of a brand (e.g., quality, price, service). That's why creating and guiding the customer experience is so important. Experience creates emotion, emotion fuels engagement and both together impact brand and business outcomes" (n.p.).

\section{Engagement: Moving Beyond the Buzzword}

Clearly, both librarians and business people recognize engagement as integral to their respective missions. The shift from "product-provider to partner" (Economist Intelligence Unit 2007, Part II:4) in the business world is similar to the discussion around library liaisons "moving from a collection-centered model to an engagement-centered one" (Williams 2009, 3). Terms and phrases such as, "collaboration," "mutually-beneficial relationships," and "emotional connection" often accompany discussions of engagement in both areas, connoting an assumed or inherent good. What is less clear is what engagement is, and how one creates, leverages, and measures it. This problem is not endemic to librarianship, as the business world is also struggling to operationalize this concept. As one researcher states, the term "customer engagement" is "embryonic" (Jaakkola and Alexander 2014, 247). Relatively speaking though, the business literature evidences a longer track record of analyzing this definition than library literature; as a result, librarians may be able to borrow from these efforts for their own purposes. Among the core difficulties of defining engagement are its multifaceted nature and its entanglement with closely-related concepts. This fact is, perhaps, most self-evident in the various types of engagement one encounters, such as "customer engagement," "brand engagement," "employee engagement," "civic engagement," and "student engagement," to name a few.

Research undertaken by Hollebeek (2011) that attempted to define the concept of “customer brand engagement" serves as a roadmap through engagement's fundamental complexities and interrelationships. Hollebeek cites previous work noting that engagement has 
been reviewed by academics in disciplines as wide-ranging as sociology, psychology, political science, and organizational behavior (786). She further outlines the many constructs (or concepts) that the literature has identified as conceptually related to engagement:

- Involvement

- Interactivity

- Flow

- Rapport

- Co-created value

- Brand experience

- Perceived quality

- Customer satisfaction

- Trust

- Commitment

- Customer value

- $\quad$ Brand loyalty (793).

Further complicating a coherent understanding of engagement is evidence that for some customers in some contexts, these constructs can be both antecedents and consequences of engagement. Hollebeek notes in the case of brand engagement, "the concepts of rapport, trust, commitment, and customer satisfaction are labelled as potential customer brand-engagement consequences for new and/or existing customers, while these may also represent engagement antecedents primarily for existing customers" (2011, 794-795). 
When attempting to understand engagement, then, one must contend with also understanding its many related constructs, as well as tackling the chicken-and-egg question as to whether one's efforts appeal to already-engaged customers, or help cultivate newly-engaged customers.

These complexities are widely acknowledged in the business literature. As Brodie et. al. summarized in their literature review, "the reviewed definitions predominantly represent engagement as a multidimensional concept. However, the expression of specific cognitive, emotional, and/or behavioral dimensions varies considerably across engagement actors (i.e., engagement subjects/objects) and/or contexts" $(2011,254)$. Brodie's work is arguably the most compelling in the business (marketing) field as it proposes a definition of customer engagement that is intended to be generally applicable across contexts. This definition, therefore, should extend to libraries as well.

To arrive at a general definition, Brodie et. al. analyzed engagement literature across disciplines to arrive at an encompassing definition of engagement composed of five common themes that are loosely described below (2011, 258-259). Customer engagement:

1. Reflects a customer's psychological state in response to interactive experiences with a "focal engagement object."

2. Occurs within a process "typified by the cocreation of value."

3. Has a central role in service relationships.

4. Is a multidimensional concept that is customer and/or context-dependent.

5. Occurs within "specific sets of context-dependent conditions generating different levels of [customer engagement]."

As the authors point out, the first two themes distinguish customer engagement from other constructs in that they require that customers participate in experiences that they co-create with 
service providers. Drawing from this definition, librarians need to explore ways to cede some control of services to users in order to nurture truly engaged users. Vivek, Beatty, and Morgan describe this shift of control that promotes engagement as, "a consumption environment where the customer has transcended from the state of being a passive audience and welcomes opportunities for connection with objects, events, people, and institutions" $(2012,133)$. This implication is important for liaison and outreach relationships in particular, as librarians should not only seek to apply their expertise to solving users' problems through these partnerships, but also invite reciprocal exchanges that inform changes to library offerings and help solve library problems.

Also important to recognize, is that one need not make a purchase to be an engaged customer, as Vivek, Beatty, and Morgan found: “Our conceptualization of CE [customer engagement] contributes to the area by reemphasizing the importance of broadly understanding individuals' interactions and connections with the brand or product and with each other relative to the brand, regardless of whether they are purchasing or even considering purchasing a brand" (2012, 137). For libraries, a purchase could be a service "use" such as consulting with a librarian or checking out a book. But as these researchers assert, users can become engaged by interacting with other users, through social media, by being exposed to advertising, and so on, regardless of whether they actually "use" the library. Therefore, librarians should be mindful of their overall image and of the less direct touchpoints with users as they can influence engagement as well.

\section{The Engaging Liaison Librarian}

What, then, can librarians apply from the relatively robust engagement research and experience within the business community to their own practice? One possible answer is slight but significant modifications of existing liaison approaches and philosophies to delve beyond 
interactions and partnerships to true engagement. As previously discussed, Gibson and Dixon outlined a definition of library engagement that rightly hinges on working collaboratively with patrons to address common interests. Furthermore, the business literature suggests the importance of the less rationale aspects of an engaging relationship that draw in parties on an emotional level. Liaisons, then, should be exceptionally mindful and strategic about the problems that they work with patrons to solve. Those problems must be those that patrons deeply care about addressing so that they are more likely to transcend from a passive state to become willing participants who welcome new connections.

To put another way, liaisons' work should be focused, less on how the library fits into the work of their target patrons, but on the problems, issues, and challenges of those patrons. Doing so requires keen interviewing and listening skills to critically evaluate core user needs that have the potential to draw parties together. Those problems, if correctly identified, can become the central focus around which engagement can be fostered.

Take, for example, the success of Airbnb - a company that connects travelers with accommodations all over the world through its online booking platform. The company addresses a real and pressing problem for travelers (affordable lodging) but its model depends on deep engagement between hosts and travelers. It gives people forums and tools for creating their own logos and a sharing their stories through videos (Airbnb, Inc.). The videos in particular showcase the relationships and discoveries made between hosts and guests. They do not overtly discuss Airbnb, but portray personal vignettes. This Airbnb engagement strategy recognizes the centrality and importance of the personal connections that drive the service. Certainly, these activities benefit Airbnb, but the primary focus is on building trust among users by building emotional connections. In a similar vein, library liaisons can potentially create and sustain deep 
engagement by devising tools and outreach strategies that showcase users and their work to solve problems with the library as a collaborator, rather than pushing users to incorporate library services and materials. This tact is somewhat nuanced, but important. To invoke Brodie et. al.'s definition of engagement, the context and "focal engagement object" are essential elements of engagement. If these are not carefully evaluated, it is less likely engagement will flourish. Therefore, careful attention should be paid to ensuring that the projects librarians undertake are truly those that users have strong stakes in, and that their interest is not superficial in nature.

As noted above, there are a number of emerging research and learning trends that are impacting academic library users, and any of those can be approached with engagement in mind. One example of a possible area ripe for engagement is open access. As reported in The Chronicle of Higher Education, researchers are now challenged by new grant stipulations that require they make their research openly accessible (McIntire 2015). Certainly, resolving this concern is of major concern to researchers whose work could be threatened if they fail to comply. Vandegrift articulates this engagement opportunity: "the new rules are giving libraries a way to forge more interaction with professors and are helping to define a new role for the research library...plenty of people have been struggling for a long time to figure out how to have that conversation with the faculty" (quoted in McIntire 2015). Identifying the new needs created by larger trends such as this one is a way librarians can find the problems well-suited for exploring engagement.

\section{The Risks of Engagement}

Engagement, while it may be based upon a variety of somewhat subjective elements, is ultimately a rational, calculated strategy with measurable outcomes. Part of this calculation must include the costs and risks, both financial and cultural, to achieve connections that will produce results. 
Libai articulates a number of important precautions one should take when targeting and catering to the most engaged users, or, what he calls, "good customers" (2011, 275). First, he suggests that the number of highly engaged customers, for most organizations, represents a very small portion of all customers; however, their influence can be disproportionate. Instead, he advises to think of them as "a large focus group." Furthermore, in allowing these vocal, engaged customers to co-create products and services, one should consider if their views accurately represent those of the majority or most profitable of customers. As he put it, "the value that highly engaged customers try to cocreate with the firm might not always be in the best interests of the firm" $(2011,275)$. As librarians work to harness the power of their constituents, it is important to seek out diverse perspectives and balance liaison engagement goals with available resources and institutional priorities to create services that speak to the needs of specific groups and also benefit the overall mission of the library.

\section{Conclusion and Recommendations}

Even though libraries and for-profit businesses might seem to be motivated by nearly opposite goals, they are aligned in their desire to engage the people who patronize their services and sustain their existence. A prerequisite for engaging people is to understand what that goal means in commonly-understood terms that can be readily applied to strategic initiatives.

Academic business researchers have made significant strides in operationalizing the complicated, multi-faceted concept of engagement so that it can be purposefully applied. Librarians can benefit from this work in addressing their user bases and unique challenges.

What is most apparent in this review of the business literature is the imperative to cocreate, rather than dictate, value to users. Engaged users are those who pass a threshold from passive recipient of services to a proactive, involved partner who desires a role in shaping the 
services they receive. To put it another way, librarians who want to achieve engagement should not expect to influence users' work without being prepared to allow users a voice in the delivery of library services. Liaison librarians, for example, should explore ways to involve their users in creating solutions to meet researcher needs, rather than only allowing users to receive predefined solutions. This shift in roles can be a difficult one for organizations to accommodate. Doing so requires giving up a measure of control, which may result in alienating some users. If successful, the rewards can be worthwhile. Engaged users can infuse libraries with innovative and relevant ideas, secure repeat use, and create willing evangelists to recruit other users. 
Moving Users, Moving Results: Exploring Customer Engagement 16

\section{References}

(ACRL) Association of College \& Research Libraries. 2015. Environmental Scan 2015. http://www.ala.org/acrl/sites/ala.org.acrl/files/content/publications/whitepapers/Environm $\underline{\text { entalScan15.pdf }}$

Airbnb, Inc. Create Airbnb. https://create.airbnb.com

Bidney, Marcy. 2014. "The Library as Platform: Assessing Outreach and Engagement in the Library of the Future." In Assessing Liaison Librarians: Documenting Impact for Positive Change, edited by Daniel C. Mack and Gary W. White, 105. Chicago, IL: Association of College and Research Libraries.

Brodie, Roderick J., Linda D. Hollebeek, Biljana Jurić, and Ana Ilić. 2011. "Customer Engagement: Conceptual Domain, Fundamental Propositions, and Implications for Research." Journal of Service Research 14 (3): 252-271. doi:10.1177/1094670511411703

Daniel, Linda, Jean Ferguson, Teddy Gray, Aisha Harvey, Diane Harvey, Danette Pachtner, and Kristinia Troost. 2011. Engaging with Library Users: Sharpening our Vision as Subject Librarians for the Duke University Libraries. http://library.duke.edu/sites/default/files/dul/about/subject-librarian-report-2011.pdf

Economist Intelligence Unit. 2007. Beyond Loyalty: Meeting the Challenge of Customer Engagement. Part I. http://graphics.eiu.com/files/ad_pdfs/eiu_AdobeEngagementPt_I_wp.pdf

- 2007. Beyond Loyalty: Meeting the Challenge of Customer Engagement. Part II. http://graphics.eiu.com/files/ad_pdfs/eiu_AdobeEngagementPt_II_wp.pdf

Frawley, Andy. 2015. "ROI is Dead. A New Metric Is Needed for Customer Relationships.” AdAge, March 4, 2015. 
Moving Users, Moving Results: Exploring Customer Engagement 17

http://adage.com/article/digitalnext/brands-measure-experience-

engagement/297426/

Gallup. 2014. State of the American Consumer: Insights for Business Leaders.

http://products.gallup.com/171722/state-american-consumer.aspx

Gibson, Craig and Christopher Dixon. 2011. "New Metrics for Academic Library Engagement." In Declaration of Interdependence: The Proceedings of the ACRL 2011 Conference, ed. Dawn M. Mueller, 340-351. Chicago, IL: Association of College and Research Libraries. http://www.ala.org/acrl/sites/ala.org.acrl/files/content/conferences/confsandpreconfs/nati onal/2011/papers/new_metrics.pdf

Hollebeek, Linda D. 2011. "Demystifying Customer Brand engagement: Exploring the Loyalty Nexus." Journal of Marketing Management 27(7-8): 785-807. doi: 10.1080/0267257X.2010.500132

Jaakkola, Elina and Matthew Alexander. 2014. "The Role of Customer Engagement Behavior in Value Co-Creation: A Service System Perspective.” Journal of Service Research 17(3): 247-261. doi: 10.1177/1094670514529187

Jaguszewski, Janice M. and Karen Williams. 2013. New Roles for New Times: Transforming Liaison Roles in Research Libraries. Washington, D.C.: Association of Research Libraries. http://www.arl.org/storage/documents/publications/nrnt-liaison-rolesrevised.pdf

Libai, Barak. 2011. "The Perils of Focusing on Highly Engaged Customers.” Journal of Service Research 14(3): 275-276. doi: 10.1177/1094670511414583

McIntire, Mary Ellen. 2015. "Librarians Leap to the Aid of Researchers Whose Funding Will Soon Depend on Open Access." The Chronicle of Higher Education, July 30. 
The Ohio State University Libraries. A Framework for the Engaged Librarian: Building on our Strengths. Accessed March 19, 2015. https://carmenwiki.osu.edu/download/attachments/37010332/Engaged+Librarian+Docum ent.pdf?version $=1 \&$ modificationDate $=1362663472574$

Van Der Werf, Martin and Grant Sabatier. 2009. The College of 2020: The Students. Chronicle Research Services.

Varki, Sajeev and Shirley Wong. 2003. "Consumer Involvement in Relationship Marketing of Services.” Journal of Service Research 6(1): 83-91. doi: 10.1177/1094670503254287

Vivek, Shiri, Sharon E. Beatty, and Robert M. Morgan. 2012. "Customer Engagement: Exploring Customer Relationships beyond Purchase." Journal of Marketing Theory and Practice 20(2): 127-145. doi: 10.2753/MTP1069-6679200201

Williams, Karen. 2009. "A Framework for Articulating New Library Roles." Research Library Issues: A Bimonthly Report from ARL, CNI, and SPARC, 265, 3-8. http://publications.arl.org/rli265 